\title{
A Comparison of the Effects of Packaging Containing Nano ZnO or Polylysine on the Microbial Purity and Texture of Cod (Gadus morhua) Fillets
}

\author{
Małgorzata Mizielińska *, Urszula Kowalska, Michał Jarosz and Patrycja Sumińska \\ Center of Bioimmobilisation and Innovative Packaging Materials, Faculty of Food Sciences and Fisheries, \\ West Pomeranian University of Technology Szczecin, Janickiego 35, 71-270 Szczecin, Poland; \\ urszula.kowalska@zut.edu.pl (U.K.); michal.jarosz@zut.edu.pl (M.J.); patrycja.suminska@zut.edu.pl (P.S.) \\ * Correspondence: malgorzata.mizielinska@zut.edu.pl; Tel.: +48-91-449-6132
}

Received: 13 February 2018; Accepted: 8 March 2018; Published: 12 March 2018

\begin{abstract}
Portions of fresh Baltic cod fillets were packed into cellulose boxes (control samples), which were covered with Methyl Hydroxypropyl Celluloses (MHPC) coating with $2 \%$ polylysine. The cellulose boxes had square PE films and were enclosed in MHPC coating containing ZnO nanoparticles. The cod fillets were stored at $5{ }^{\circ} \mathrm{C}$ and examined after $72 \mathrm{~h}$ and $144 \mathrm{~h}$ storage times. Results obtained in this study showed that the textural parameters of the cod fillets increased, with both Springiness and Cohesiveness found greater after $144 \mathrm{~h}$ of storage for all analysed packaging materials. The Gumminess of fillets increased after storage, but the lowest increase was noted in cod samples that were stored in boxes containing PE films with $\mathrm{ZnO}$ nanoparticles. It was found that water loss from the cod fillets in these boxes was also lowest. The Adhesiveness of the fish samples stored in boxes devoid of active coatings also increased. In contrast to the packaging material devoid of active coatings, the storage of fillets in active coating boxes resulted in a decrease of adhesiveness. Microbial analysis showed that packaging material containing nano- $\mathrm{ZnO}$ was found to be more active against mesophilic and psychotropic bacterial cells than the coatings with polylysine after $72 \mathrm{~h}$ and $144 \mathrm{~h}$ of storage.
\end{abstract}

Keywords: cod fillets; Gadus morhua; $\mathrm{ZnO}$ nanoparticles; antimicrobial coatings; texture; active packaging

\section{Introduction}

Fish and fish products have high nutritional value and contain beneficial amounts of protein, lipids, essential minerals, and vitamins. However, fish are often considered to be difficult foodstuffs due spoilage and oxidation problems, as well as the development of off-flavours from improper handling or incorrect storage [1]. Fish spoilage is primarily caused by microbial growth and metabolism, and is characterized by changes in the sensory properties leading to unacceptable product quality. The shelf life of fish is affected by several factors, including storage temperature, fish species, initial microbial contamination and packaging conditions. Even though $10^{7} \mathrm{cfu} / \mathrm{g}$ is generally considered a maximum acceptable microbial load for fish, sensory rejection is typically found at microbial levels between $10^{6}$ and $10^{9} \mathrm{cfu} / \mathrm{g}$ [2]. The shelf life of fresh fish is generally limited by the growth of psychotropic Gram-negative rod-shaped bacteria along with Gram-positive microbes. In marine fish stored under refrigerated aerobic conditions, Pseudomonas sp. and Shewanella spp. have been observed to dominate [1,2]. As a result of microbial metabolism, odour is one of the most important quality determinants for fish freshness. Volatile organic compounds (VOCs), such as acids, alcohols, aldehydes, amines, ketones and sulphides, are often produced by bacteria leading to the production of characteristic off-odours and off-flavours [2]. Raw material quality and low storage temperature significantly reduce any deterioration in product quality, though time remains a highly limiting 
variable [3,4], with the preservation of the high nutritional quality of fish being of significant importance. Preservation methods that were studied in the 1980s sought to preserve fish and extend its shelf life using safe chemical preservatives such as potassium sorbate, shown to inhibit the bacteria responsible for spoilage odour. The addition of $2.5 \%$ and $5.0 \%$ of Potassium Sorbate to cod fillets, as well as packaging them in either $0.75 \mathrm{~mm}$ LDPE increased the shelf life of the fish by up to 16 days [5].

Active packaging is an innovative approach to maintain or prolong the shelf life of food products while ensuring their quality, safety and integrity [6,7]. Modified atmosphere packaging (MAP) can significantly prolong the shelf life of cod at chilled temperatures. Numerous studies have been carried out on the effects of MAP on the shelf life and quality retention of cod [8]. The reported shelf life of MA packed cod ranges from 10 to around 20 days at 0 to ${ }^{\circ} \mathrm{C}[3,4,8]$. Antimicrobial active packaging is a promising technology for the improvement of safety, and to delay spoilage during the processing and handling of fish. Applying antibacterial substances directly onto the surface of the fish has limited benefits, being neutralized on contact, or diffusing rapidly into the fish. The application of antimicrobial agents incorporated into a polymer matrix or their use as active coatings for covering packaging materials is a wide area of research for seafood packaging [1,6].

Recently, new types of nano-inorganic antimicrobial materials have become widely used in many fields, due to their stability at high temperatures and pressure conditions, they are generally considered safer for human and animals in contrast to organic substances. Antimicrobial polymers containing silver ions $\left(\mathrm{Ag}^{+}\right)$are preferred for their wide spectrum of antimicrobial activity, safety and heat stability [1]. Several researchers have blended $\mathrm{PE}$ with $\mathrm{Ag}, \mathrm{TiO}_{2}$, and kaolin nanopowders for the preservation of fresh food stored at $4{ }^{\circ} \mathrm{C}$ for 12 days. Zinc Oxide ( $\mathrm{ZnO}$ ) nanoparticles have also been explored as an antimicrobial agent, used in active food packaging systems. These nanoparticles are recognised as safe (GRAS) by the United States food and drug administration (USFDA, 21CFR182.8991) [9-11]. Zinc Oxide nanoparticles offer bactericidal effects for Gram-positive and Gram-negative bacteria and to spores that are resistant to high temperature and high pressure, as well as yeasts and moulds [11]. Zinc Oxide nanoparticles have been incorporated into polymers and have been added to biodegradable active coatings [7,11-14]. Numerous studies have shown an increase in the shelf life of food products packed in films containing ZnO nanoparticles (within a polymer matrix or added into an active coating) [15-18]. The shelf life of sliced wheat bread was extended from 3 to 35 days using packaging containing nanoparticles when compared to control versions [15]. All active coatings reduced the number of microorganisms in sliced bread for up to 15 days. Films containing nano-ZnO exhibited excellent antimicrobial activity and were fabricated into packaging pouches for raw meat. The prepared pouches showed significant action against bacteria in the meat, offering complete inhibition of microbial growth for to six days of storage at $4{ }^{\circ} \mathrm{C}$ [4]. Emamifar et al. [19] reported that LDPE nanocomposite packaging materials containing Ag and ZnO nanoparticles were conducive in prolonging the shelf-life of fresh orange juice in storage at $4{ }^{\circ} \mathrm{C}$. Li et al. [20-22] successfully developed a packaging material containing nano-ZnO particles as active food packaging to improve the shelf-life of freshly cut apple. However, one shortcoming relating to the use of nanoparticles in food packaging is the migration of nanoparticles from the packaging materials to the food, which can harm human health and have a negative effect on environmental safety. Li et al. [21,22] confirmed that the amounts of nanoparticle migration from the nano-blend film to cheese samples and food simulants were far below the migration limit of $1 \mathrm{mg} / \mathrm{kg}$ as defined by EFSA for food contact materials. $\varepsilon$-Polylysine (PL) as a natural antimicrobial polypeptide is also recognized as safe and the antimicrobial action of PL is attributed to its polycationic and surface nature that enables its interaction with bacterial membranes. The polypeptide is active against $\mathrm{G}(+)$ and G(-) food pathogenic bacteria including Listeria monocytogenes, Escherichia coli O157:H7 and Salmonella Typhimurium. However, studies in the literature related to use of PL in antimicrobial packaging are scarce. Zinoviadou [23] is noted as the first researcher using PL in whey protein films and successfully applying the developed films to control the spoilage flora of fresh beef. Ünalan [24] analysed the antimicrobial properties of edible films from whey proteins, alginate, zein and chitosan incorporated 
with polylysine. PL is also used in Japan as an antimicrobial preservative in foods. Different Japanese foods that contain PL include sliced fish and fish surimi, boiled rice, noodle soup stocks, noodles and cooked vegetables [24].

The purpose of this research was to compare the effect of packaging containing nano $\mathrm{ZnO}$ or polylysine on microbial purity and cod fillet texture.

\section{Materials and Methods}

Fresh Baltic cod fillets (Gadus morhua callarias) (Świeża-Ryba.pl, Szczecin, Poland) were ordered online (Świeża-Ryba.pl) and brought (in polystyrene (PS) boxes containing ice) to the Center of Bioimmobilisation and Innovative Packaging Materials (CBIMO).

Cellophane/Biopolyethylene films (Cel/PE, (A4, $50 \mu \mathrm{m})$ (Be Nature, Schoten, Belgium) were used in this research. Methyl Hydroxypropyl Cellulose (MHPC, Chempur, Piekary Ślaskie, Poland) and Methyl Cellulose (Methocel ${ }^{\mathrm{TM}}$, Dow, Stade, Germany) were used as coating carriers. Zinc Oxide AA $44,899,(\sim 70 \mathrm{~nm})$ and polylysine (Handary, Uccle, Belgium) were used as active substances. To verify the antimicrobial purity of the cod fillets, PPS, PCA and MRS mediums (Biocorp, Warsaw, Poland) were used. The mediums were prepared according to the Biocorp protocol (all mediums were weighed according to the manufacturer's instructions, then suspended in $1000 \mathrm{~mL}$ of distilled water and autoclaved at $121^{\circ} \mathrm{C}$ for $15 \mathrm{~min}$ ).

Cellulose boxes (Celabor, Herve, Belgium) and PE films were used as packaging materials for the fresh cod fillets.

\subsection{Coatings Preparation}

(1) Two grams of Methocel ${ }^{\mathrm{TM}}$ were introduced into $96 \mathrm{~mL}$ of water. The mixture was mixed for $1 \mathrm{~h}$ using a magnetic stirrer (Ika) at $1500 \mathrm{rpm}$. Next, $2 \mathrm{~g}$ of polylysine were introduced into $98 \mathrm{~g}$ of mixture. The mixture was then mixed for $1 \mathrm{~h}$ using a magnetic stirrer (Ika) at $1500 \mathrm{rpm}$. The mixture was used to cover the cellulose boxes to obtain $2 \%$ polylysine coatings as active substance.

(2) Exactly $0.082 \mathrm{~g}$ of $\mathrm{ZnO}$ nanoparticles were introduced into $50 \mathrm{~mL}$ of water. Initially, the mixture was mixed for $1 \mathrm{~h}$ using a magnetic stirrer $(450 \mathrm{rpm})$. Next, the mixture was sonicated (sonication parameters: cycle: 0.5 ; amplitude: $20 \%$; time: $10 \mathrm{~min}$ ), while, at the same time, a second mixture (4 $\mathrm{g}$ of MHPC into $50 \mathrm{~mL}$ ) was prepared as described above. The $\mathrm{ZnO}$ nanoparticles solution was introduced into the MHPC mixture and sonicated (sonication parameters: cycle: 0.5; amplitude: 20\%; time: $10 \mathrm{~min})$.

Polyethylene (PE) films (20 $\mu \mathrm{m}, \mathrm{CBIMO}$ - Center of Bioimmobilisation and Innovative Packaging Materials, Szczecin, Poland) were covered using Unicoater 409 (Erichsen, Hemer, Germany) at $25^{\circ} \mathrm{C}$ with a roller at a diameter of $40 \mu \mathrm{m}$. The coatings were dried for $10 \mathrm{~min}$ at a temperature of $50{ }^{\circ} \mathrm{C}$. Finally, $1.6 \mathrm{~g}$ layers of MHPC per $1 \mathrm{~m}^{2}$ of PE were obtained. The active coatings contained $0.032 \mathrm{~g}$ of ZnO AA 44,899 particles per $1 \mathrm{~m}^{2}$ of PE film.

The covered film samples were cut into square shapes $(9 \mathrm{~cm} \times 9 \mathrm{~cm})$ and introduced into the cellulose boxes.

\subsection{Packaging and Storage}

The fresh Baltic cod fillets were cut into $25 \mathrm{~g}$ pieces. The cod portions were packed into cellulose boxes that were welded with Cel/PE films. The samples were aseptically introduced into:

a. Cellulose boxes (control samples) (Figure 1a,d);

b. Cellulose boxes covered with a Methocel ${ }^{\mathrm{TM}}$ coating with $2 \%$ polylysine (Figure $1 \mathrm{~b}, \mathrm{~d}$ ); and

c. Cellulose boxes with square PE films covered with MHPC coating containing ZnO nanoparticles (Figure 1c,d). 
The fillets were put on the film squares and covered with the PE square films. The cod fillets were in contact with the active coatings on both sides.

Next, the boxes were joined with Cel/PE films using a welder (HSE-3, RDM Test Equipment, Hertfordshire, UK) in normal air conditions. The parameters of welding were: Temperature, $145^{\circ} \mathrm{C}$ (box covered with coating) and $150^{\circ} \mathrm{C}$ (box devoid of coating); Pressure, $3 \mathrm{kN}$; and time, $1 \mathrm{~s}$.

The boxes containing cod fillets were then stored in a refrigerator. The samples were stored at $5{ }^{\circ} \mathrm{C}$. The cod fillets were examined after $72 \mathrm{~h}$ and $144 \mathrm{~h}$ of storage.

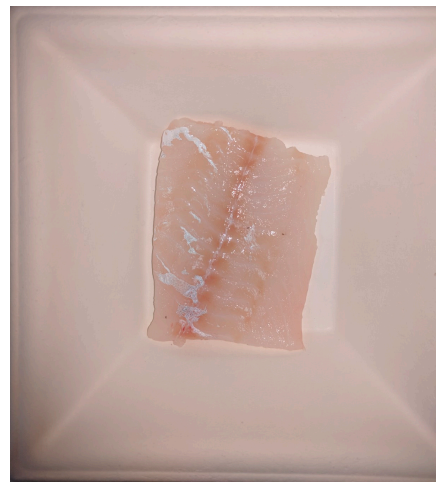

(a)

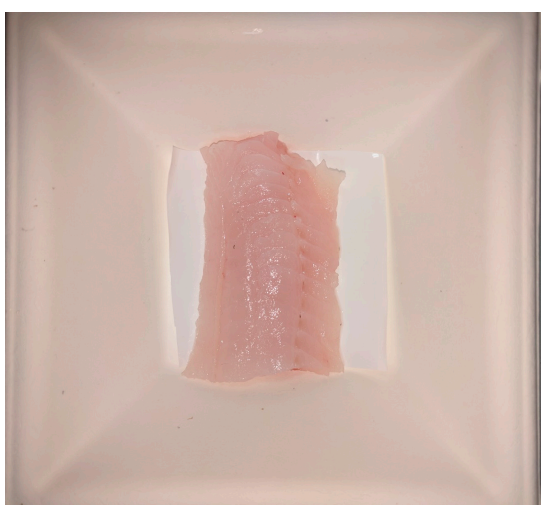

(c)

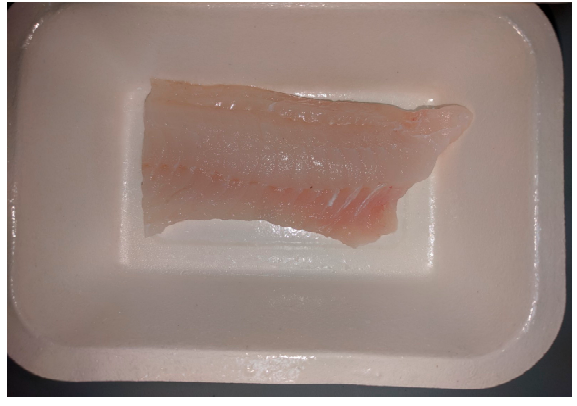

(b)

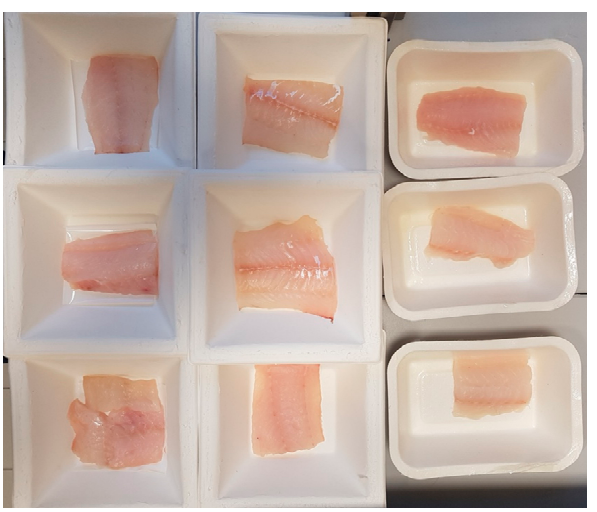

(d)

Figure 1. (a) The cod in the control box; (b) the cod in the box covered with a coating with polylysine; (c) the cod in the box covered with a coating with $\mathrm{ZnO}$ nanoparticles; and (d) the cod before welding.

\subsection{Mechanical Analysis}

The texture analysis of the cod fillets was carried out according to the PN-ISO 11036:1999 standard: "Sensory analysis. Methodology. Texture profiling" [25]. The tests were carried out using Zwick/Roell Z 2.5 (Wrocław, Poland).

\subsection{Microbiological Purity}

For microbiological analysis, $25 \pm 0.1 \mathrm{~g}$ of individual fillet was aseptically introduced into a sterile stomacher bag and in physiological saline peptone solution (PPS: $0.85 \% \mathrm{~m} / \mathrm{v} \mathrm{NaCl}, 0.1 \% \mathrm{~m} / v$ peptone). The samples were homogenized in a Bag Mixer (Interscience, Saint-Nom-la-Brèteche, France) for one minute and appropriate decimal dilutions were prepared in PPS. The total psychrotrophic count (TPC) and total were determined according to PN-EN ISO 4833-2:2013-12 [26]; PN-ISO 17410:2004 [27] and PN-EN ISO 6887-3:2017-05 [28] standards. 


\subsection{Dry Mass Tests}

Dry mass was measured for fresh cod (control sample) before being added into boxes after $72 \mathrm{~h}$ and $144 \mathrm{~h}$ of storage. Dry mass analysis was performed using a Weight Dryer (Radwag, Warsaw, Poland). The test was performed in duplicate.

\section{6. $L^{*} a^{*} b^{*}$ Tests}

Product colour was determined as an average of 9 measurements from randomly selected fillet spots with a colometer (NR 20XE, EnviSense) and related data software. Colour was measured through an aperture (a diameter $8 \mathrm{~mm}$ ) using the CIE $\mathrm{L}^{*} \mathrm{a}^{*} \mathrm{~b}^{*}$ colour space with a standard 10 observer and Illuminant D65. The selected parameters (to describe the results) were $\Delta E_{\text {lab }}$ (total colour aberration) and $\Delta L$ (the difference between lightness and darkness). The parameters were calculated according to an EnviSense protocol.

\subsection{Statistical Analysis}

Statistical significance was determined using an analysis of variance (ANOVA) followed by a Duncan test. The values were considered as significantly different when $p<0.05$. All analyses were performed with Statistica version 10 (StatSoft Polska, Kraków, Poland).

\section{Results}

\subsection{Microbial Purity Analysis}

Results of the study demonstrated that the amount of mesophilic bacterial cells from cod fillets stored in boxes devoid of active coatings or active films ( $\mathrm{C}$ - control sample) increased after $72 \mathrm{~h}$ of storage at $5{ }^{\circ} \mathrm{C}$ in air conditions. A 2-log increase in the number of bacteria was observed (compared to the " 0 " sample-before storage). Figure 2 shows that a Methocel ${ }^{\mathrm{TM}}$ coating containing $2 \%$ polylysine had no influence on the growth of microorganisms. A 2-log increase in the number of living cells was also observed (than compared to the " 0 " sample-before storage). It is tempting to suggest that the coating was not active against mesophilic bacteria. As emphasized below (Figure 2), the PE films covered with MHPC coating containing $\mathrm{ZnO}$ nanoparticles (introduced into boxes) decreased the number of mesophilic bacteria compared to the boxes devoid of coatings or covered with Methocel ${ }^{\mathrm{TM}}$ with $2 \%$ polylysine. A 1-log increase in the number of bacteria was noted (than compared to the " 0 " sample-before storage). Statistical analysis demonstrated that any differences between the numbers of microorganisms were not significant $(p>0.05)$.

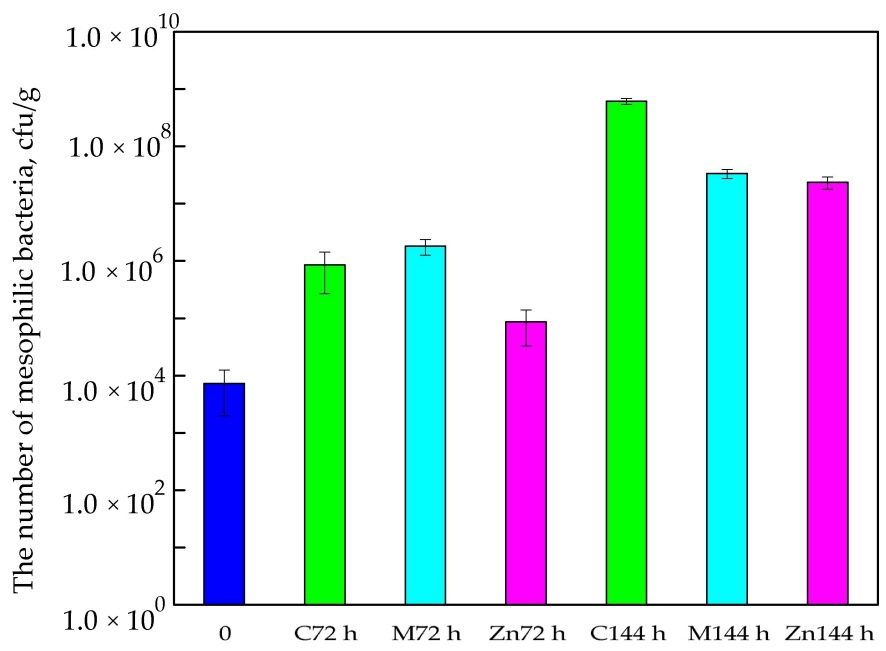

Figure 2. The number mesophilic bacteria after $72 \mathrm{~h}$ and $144 \mathrm{~h}$ of storage. 
As observed in this study, different results were obtained for cod fillets after $144 \mathrm{~h}$ storage at $5{ }^{\circ} \mathrm{C}$ in air conditions. A comparison of " 0 " samples (the number of bacteria isolated from cod fillets before storage) and control samples (the number of bacteria isolated from cod fillets stored in boxes devoid of active coatings or active films) showed that the amount of mesophilic bacteria increased significantly. A 5-log increase in the number of microorganisms was observed compared to the " 0 " samples and a 3-log increase in the number of bacteria was observed compared to control samples stored for $72 \mathrm{~h}$. The differences between the numbers of viable cells were significant, which was confirmed by a Duncan test $(p<0.05)$.

It was noted that active coatings with $2 \%$ polylysine covering the boxes and active coatings with $\mathrm{ZnO}$ nanoparticles that covered the films were active against mesophilic bacteria (for cod samples stored for $144 \mathrm{~h}$ ). A 4-log increase in the number of microorganisms was observed compared to the " 0 " samples and a 2-log increase in the number of bacteria was observed compared to control samples stored for $72 \mathrm{~h}$. The differences between the numbers of viable cells were significant, as confirmed by a Duncan test $(p<0.05)$. It should be mentioned that $10^{7} \mathrm{cfu} / \mathrm{g}$ is generally considered a maximum acceptable microbial load for fish. This means that the cod fillet shelf life stored in boxes devoid of active coatings or active films should have been less than $144 \mathrm{~h}$, as the number of mesophilic bacteria for these samples was $6.15 \times 10^{8} \mathrm{cfu} / \mathrm{g}$, a higher number than the acceptable microbial load for cod that could be consumed. A previous study [11,13] confirmed that MHPC coatings containing ZnO nanoparticles inhibited the growth of Gram-positive and Gram-negative bacteria. The results of that study demonstrated that MHPC coatings with nano-ZnO were more active against mesophilic bacterial cells than coatings with polylysine as an active substance after $72 \mathrm{~h}$ and $144 \mathrm{~h}$ of storage.

Results from our study showed that the amount of psychotropic bacteria isolated from cod fillets stored in boxes devoid of active coatings or active films (C-control sample) increased after $72 \mathrm{~h}$ of storage at $5{ }^{\circ} \mathrm{C}$ in air conditions. A 2-log increase in the number of bacteria was observed (than compared to the " 0 " sample). It was noted that boxes covered with a Methocel ${ }^{\mathrm{TM}}$ coating containing $2 \%$ polylysine were found to be the worst solution. A 3-log increase in the number of living cells was observed in these samples (than compared to " 0 "). It is tempting to suggest that the coatings must have been used as an additional carbon source by psychrotrophic bacteria. As emphasized below (Figure 3), the PE films covered with MHPC coating containing ZnO nanoparticles reduced the number of psychotropic bacteria compared to boxes devoid of coatings or covered with Methocel ${ }^{\mathrm{TM}}$ with $2 \%$ polylysine. A 1-log increase in the number of bacteria was noted (than compared to the " 0 " sample). A statistical analysis demonstrated that the differences between the numbers of microorganisms were significant $(p<0.05)$.

It was observed in this study that cod fillets could be stored for $144 \mathrm{~h}$ in $5{ }^{\circ} \mathrm{C}$ air conditions. A comparison of " 0 " samples and control samples showed that the amount of psychotropic bacteria increased significantly. A 4-log increase in the number of microorganisms was observed compared to " 0 " samples and control samples stored for $72 \mathrm{~h}$. The differences between the numbers of viable cells were significant, which was confirmed by a Duncan test $(p<0.05)$.

It was observed that active coating $\mathrm{ZnO}$ nanoparticles covering the films were active against psychotropic bacteria (for cod samples stored for $144 \mathrm{~h}$ ). A 3-log increase in the number of microorganisms was observed compared to the " 0 " samples and a 1-log increase in the number of bacteria was observed than when compared to the control samples and M samples stored for $72 \mathrm{~h}$. The differences between the numbers of viable cells were significant, and this was confirmed by a Duncan test $(p<0.05)$. It should be mentioned that the number of microorganisms in cod fillets stored in boxes containing $\mathrm{ZnO}$ nanoparticles was $10^{6} \mathrm{cfu} / \mathrm{g}$. This suggests that the shelf life of the cod fillets packed in these boxes could be greater than $144 \mathrm{~h}$. The results of the study showed that the MHPC coatings with nano- $\mathrm{ZnO}$ were more active against psychotropic bacterial cells than coatings with polylysine as an active substance after $72 \mathrm{~h}$ and $144 \mathrm{~h}$ storage. 


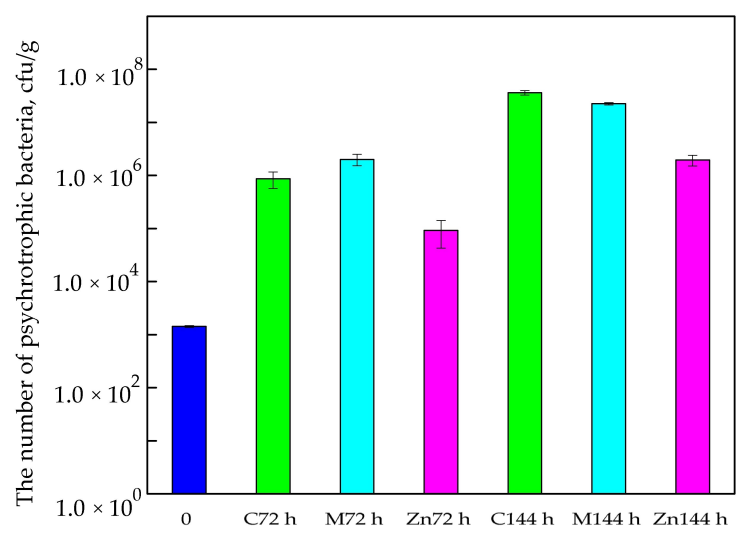

Figure 3. The number psychotropic bacteria after $72 \mathrm{~h}$ and $144 \mathrm{~h}$ of storage.

\subsection{Mechanical Analysis}

The results of the study demonstrated that the Springiness of the cod fillets increased after $72 \mathrm{~h}$ of storage in boxes devoid of active coatings or active films. After $144 \mathrm{~h}$ this parameter decreased. A modification of the boxes with active coatings containing polylysine as an active substance caused a greater increase in the cod fillet Springiness after $72 \mathrm{~h}$ and $144 \mathrm{~h}$ storage (Figure 4). The differences between Springiness values were found to not be significant, and this was confirmed by statistical analysis $(p>0.05)$. An increase in the Springiness of the cod fillets stored in boxes containing $\mathrm{ZnO}$ nanoparticles after $72 \mathrm{~h}$ and $144 \mathrm{~h}$ was also observed.

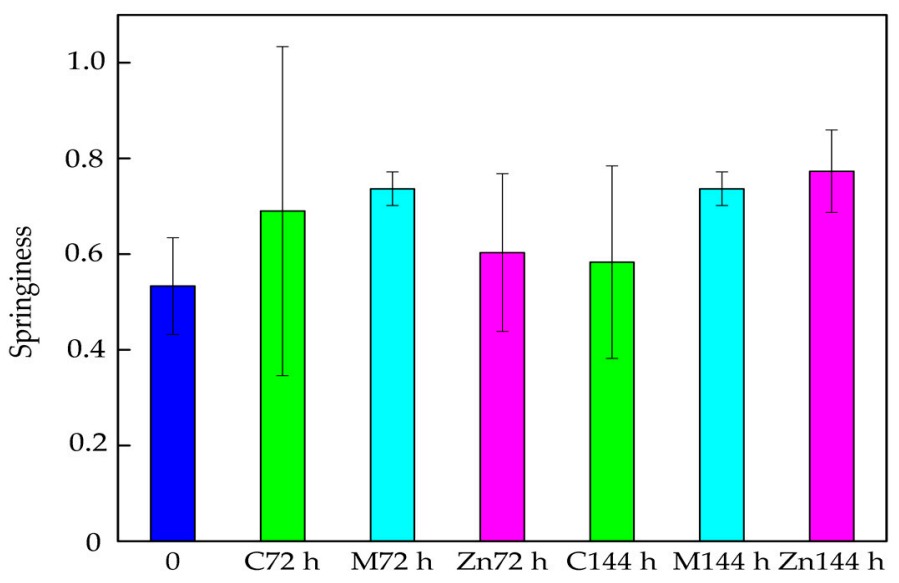

Figure 4. The Springiness of the cod fillets after 72 and $144 \mathrm{~h}$ of storage.

As emphasized below (Figure 5), the Gumminess of cod samples stored in boxes devoid of active films or coatings (control sample) increased after $72 \mathrm{~h}$ and $144 \mathrm{~h}$ than compared to the " 0 " sample. These changes were significant and were confirmed by Duncan test $(p<0.05)$. Similarly, Methocel ${ }^{\mathrm{TM}}$ coatings with polylysine caused a significant increase in this parameter after $72 \mathrm{~h}$ of storage, again, confirmed by a Duncan test $(p<0.05)$. After $144 \mathrm{~h}$ of storage, the average Gumminess value of the cod fillets stored in boxes covered with Methocel $^{\mathrm{TM}}$ containing polylysine, decreased when compared to the Gumminess value of the samples stored for $72 \mathrm{~h}$, and increased compared to the " 0 " sample. The differences between Gumminess values were found to not be significant, which was confirmed by statistical analysis $(p>0.05)$. Additionally, after $72 \mathrm{~h}$ and $144 \mathrm{~h}$ storage, the Gumminess of the cod stored in boxes with PE films covered with MHPC coatings containing ZnO nanoparticles showed a slight increase compared to the Gumminess value obtained from the " 0 " sample. The differences between Gumminess values were not significant, which was confirmed by Duncan test $(p>0.05)$. 
In the case of cohesiveness, it was observed that the average parameter value for the fillets stored in boxes prepared as control samples increased after $72 \mathrm{~h}$ storage (Figure 6). These changes were significant and confirmed by Duncan test $(p<0.05)$. The average Cohesiveness value, measured for the same samples, but stored for $144 \mathrm{~h}$ also increased, although the amount was small. The differences between Cohesiveness values were found to not be significant, again confirmed by statistical analysis $(p>0.05)$. A Significant increase in this parameter was observed for samples stored for $72 \mathrm{~h}$ in coated boxes (control samples) $(p<0.05)$. After $144 \mathrm{~h}$ storage, a decrease in cod Cohesiveness was observed, but the differences were found to not be significant $(p>0.05)$. An increase in fillet Cohesiveness was also observed for samples stored for $72 \mathrm{~h}$ and $144 \mathrm{~h}$ in packaging containing $\mathrm{ZnO}$ nanoparticles. It should be mentioned that the increase was not significant, again confirmed by Duncan test $(p>0.05)$.

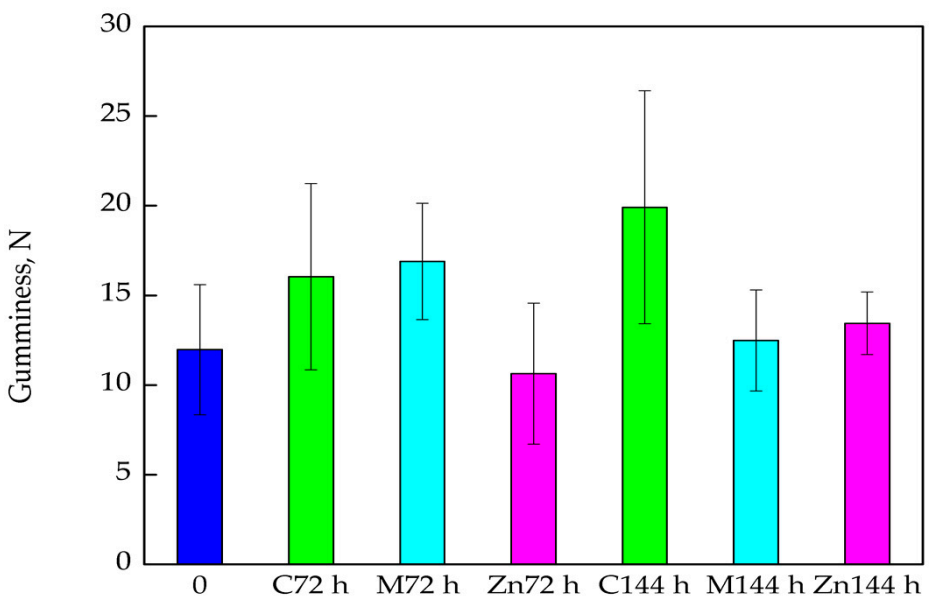

Figure 5. The Gumminess of the cod fillets after 72 and $144 \mathrm{~h}$ of storage.

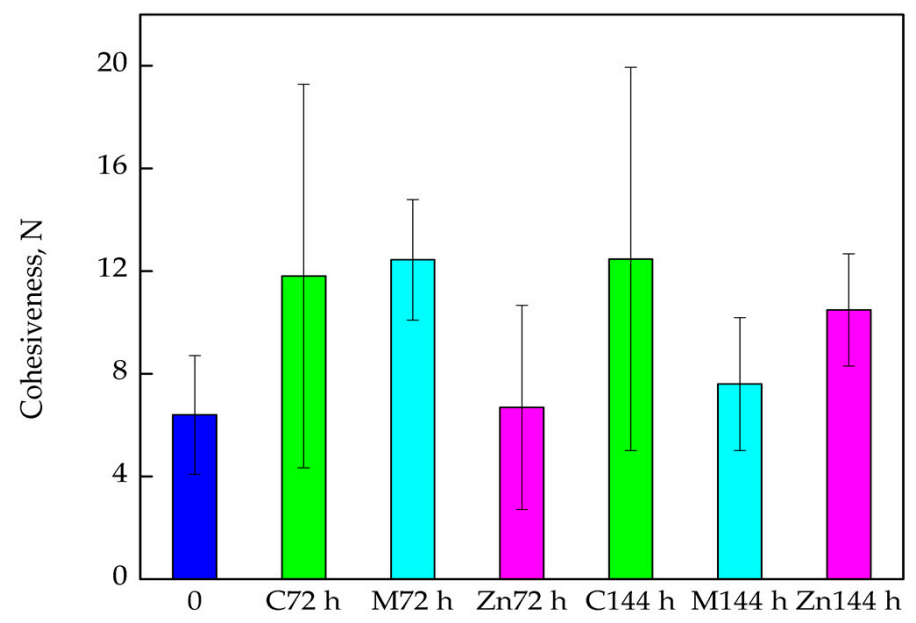

Figure 6. The Cohesiveness of the cod fillets after 72 and $144 \mathrm{~h}$ of storage.

The results showed that Adhesiveness was a parameter that clearly depended on the packaging material (Figure 7). Analysing the Adhesiveness values of the cod fillets that were introduced into boxes devoid of active coatings or covered PE films for $72 \mathrm{~h}$, it was noted that this parameter increased, though not significantly $(p>0.05)$. After $144 \mathrm{~h}$ storage an increase was found to be significant and this was confirmed by Duncan test $(p<0.05)$. Adhesiveness of all cod samples that were introduced into the boxes that were covered with Methoce ${ }^{\mathrm{TM}}$ with polylysine or into the boxes containing PE films covered with MHPC with ZnO nanoparticles, decreased after $72 \mathrm{~h}$ and after $144 \mathrm{~h}$ storage. Results showed that the modification of boxes with an active coating containing or introducing active films into the boxes changed Adhesiveness significantly, which was confirmed by statistical analysis $(p<0.05)$. 


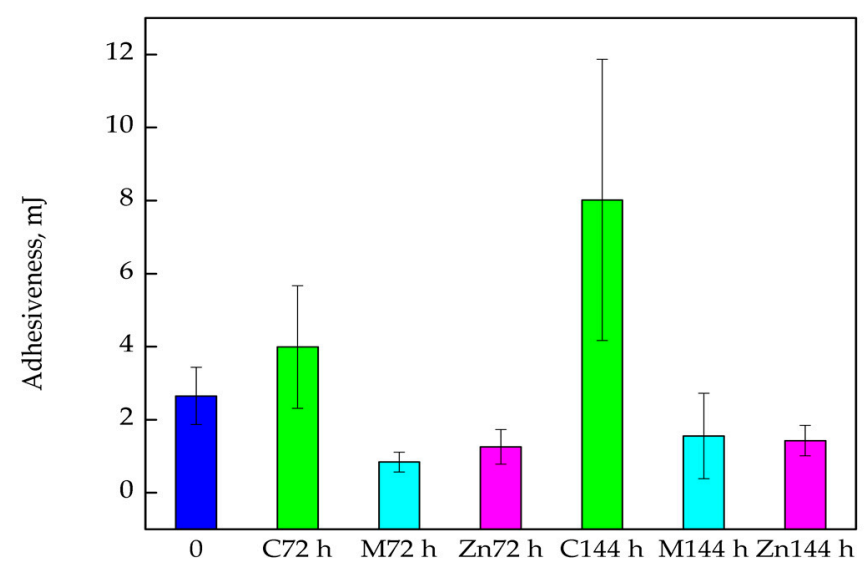

Figure 7. The Adhesiveness of the cod fillets after 72 and $144 \mathrm{~h}$ of storage.

\subsection{Dry Mass Analysis}

The results of this study demonstrated that the dry mass of fresh cod fillets was $17.64 \%$. The storage of fillets in cellulose boxes led to an increase in the dry mass of cod to $20.00 \%$ after $72 \mathrm{~h}$ storage and to $23.06 \%$ after $144 \mathrm{~h}$. It was noted that the dry mass of fillets stored in boxes covered with active coatings was higher than the dry mass of the samples stored in boxes devoid of active coating. Nanoparticles of $\mathrm{ZnO}$ led to a decrease in the dry mass of the fish fillets. Water loss was the lowest for the samples stored in boxes containing PE films covered in coatings with $\mathrm{ZnO}$ nanoparticles. The highest water loss was obtained in cod fillets stored in boxes covered with Methocel ${ }^{\mathrm{TM}}$ containing polylysine (Table 1).

Table 1. The dry mass of cod fillets after $72 \mathrm{~h}$ and $144 \mathrm{~h}$ of storage.

\begin{tabular}{ccccc}
\hline \multirow{2}{*}{ Time (h) } & \multicolumn{4}{c}{ Dry Mass (\%) } \\
\cline { 2 - 5 } & $\mathbf{0}$ & $\mathbf{C}$ & $\mathbf{M}$ & Zn \\
\hline 0 & 17.64 & - & - & - \\
72 & - & 20.00 & 22.58 & 19.18 \\
144 & - & 23.06 & 24.96 & 18.90 \\
\hline
\end{tabular}

\section{4. $L^{*} a^{*} b^{*}$ Analysis}

It was determined in this study that $\Delta E_{l a b}$ depended on the packaging material (Table 2). $\Delta E_{l a b}$ of cod fillets that were introduced into the boxes devoid of active coatings or covered PE films for $72 \mathrm{~h}$ was lower than samples introduced into the boxes containing films with $\mathrm{ZnO}$ nanoparticles. In contrast to films coated with MHPC containing nano $\mathrm{ZnO}, \Delta E_{\text {lab }}$ for samples stored in boxes covered with Methocel ${ }^{\mathrm{TM}}$, with polylysine was higher. Different results were obtained after $144 \mathrm{~h}$ storage. The highest $\Delta E_{l a b}$ was obtained for samples stored in packaging coated with an active coating. The lowest $\Delta E_{\text {lab }}$ was observed in the control sample. It was also noted that $\Delta \mathrm{L}$ was also dependent on packaging material. An analysis of cod fillets stored for $72 \mathrm{~h}$ and $144 \mathrm{~h}$, found that the highest $\Delta L$ values were obtained for samples introduced into boxes with films covered with coatings containing $\mathrm{ZnO}$ nanoparticles, and the lowest for boxes coated with Methocel ${ }^{\mathrm{TM}}$ with polylysine.

Table 2. The changes of colour of cod fillets after $72 \mathrm{~h}$ and $144 \mathrm{~h}$ of storage.

\begin{tabular}{ccccc}
\hline Time (h) & & $\mathbf{C}$ & $\mathbf{M}$ & $\mathbf{Z n}$ \\
\hline \multirow{2}{*}{72} & $\Delta E_{\text {lab }}$ & $5.45 \pm 3.00$ & $3.70 \pm 1.10$ & $18.23 \pm 0.26$ \\
& $\Delta L$ & $0.4 \pm 6.15$ & $-0.42 \pm 0.83$ & $17.91 \pm 0.44$ \\
\hline \multirow{2}{*}{144} & $\Delta E_{\text {lab }}$ & $12.57 \pm 0.70$ & $54.03 \pm 18.40$ & $21.05 \pm 5.10$ \\
& $\Delta L$ & $11.51 \pm 0.74$ & $0.49 \pm 1.98$ & $20.84 \pm 5.04$ \\
\hline
\end{tabular}




\section{Discussion}

Freshness is one of the most significant properties in the evaluation of fish quality, as this characteristic is directly linked to microbial purity, texture, and perception taste for consumers. Generally, fish is processed and frozen to guarantee palatability and safety, to improve shelf life and convenience, and to maintain and prolong freshness. The preservation of fresh cod fillets is problematic because fresh fillets undergo rapid deteriorative processes that can promote fish spoiling. At the same time, due to microbial growth, enzymatic degradation and cod fillet texture, they generally have a short shelf life [29-31]. The main mission of food packaging is to maintain the quality and safety of food products during storage and to extend shelf-life by avoiding unpleasant effects, such as hazardous microorganisms and their corresponding toxins, external physical force, chemical compounds, sunlight, permeable volatile compounds, oxygen and moisture [6,32]. Ünalan et al. [24] analysed the antimicrobial activity of edible films from whey proteins, alginate, zein and chitosan incorporated with polylysine and found polylysine to be effective against microorganisms. Numerous studies have also found $\mathrm{ZnO}$ nanoparticles to be active against microorganisms, and have shown an increase in the shelf life of food products packed in films containing incorporated $\mathrm{ZnO}$ nanoparticles (within a polymer matrix) or used with coatings containing $\mathrm{ZnO}$ nanoparticles [9-20].

One of the most important parameters determining the quality of fish fillets consumed without thermal processing is their texture and colour. This refers mainly to fish that are characterized by subtle flavour. A product that is too soft or not cohesive enough may cause problems when sliced or create doubts in the consumer as to its freshness. Cohesiveness is highly important parameter that represents forces holding the product together. On the other hand, tough, stringy or gummy products are not acceptable since they present non-specific and excessively strong resistance during mastication [33,34]. The results obtained in this study showed that the textural parameters of cod fillets after $144 \mathrm{~h}$ storage in relation to Springiness and Cohesiveness increased for all analysed packaging materials (when compared to the " 0 " sample). It is tempting to suggest that the storage of cod fillets in boxes improved the texture of fish, also backed up by Michalczyk and Surówka [33] in their results. The authors confirmed that textural parameters tended to increase during storage. The present study showed that, unfortunately, fillet Gumminess increased after storage and is considered a clear disadvantage. The best results were obtained for samples that were stored in boxes containing PE films with $\mathrm{ZnO}$ nanoparticles when the smallest increase of Gumminess in these samples was noted. It is also worth considering another advantage of the packaging material with $\mathrm{ZnO}$ nanoparticles: it was also shown that water loss in cod fillets from these boxes was the lowest. It was also observed that the highest $\Delta \mathrm{L}$ values were obtained for the fillet samples introduced into boxes with films containing $\mathrm{ZnO}$ nanoparticles. This means that the cod fillets taken from these kinds of packaging were the lightest.

The Adhesiveness of cod fillets stored in boxes devoid of active coatings also increased, contrary to packaging material devoid of active coatings, the storage of fillets in boxes with active coatings caused a decrease in adhesiveness. It should be mentioned that a greater decrease in this parameter was observed for coatings containing $\mathrm{ZnO}$ nanoparticles. The opposite results were observed by Ayala et al. [35], who analysed the textural parameters of fish fillets packed in air or vacuum conditions (into packaging devoid of any active coatings) and stored for 22 days. The authors found that the textural parameters decreased significantly with storage time.

The results of this study demonstrated that MHPC coatings with nano-ZnO were more active against mesophilic and psychotropic bacterial cells than coatings with polylysine as an active substance after $72 \mathrm{~h}$ and $144 \mathrm{~h}$ storage. The $\mathrm{ZnO}$ nanoparticles decreased the number of microorganisms due to their greater activity against Gram-positive and Gram-negative bacteria presented in the previous study [11,13]. It is known that $10^{7} \mathrm{cfu} / \mathrm{g}$ is considered a maximum acceptable number of living microbial cells for fish. This means that the shelf life of cod fillets stored in boxes devoid of active coatings should be shorter than $144 \mathrm{~h}$, as the number of mesophilic bacteria for these fillets was $6.15 \times 10^{8} \mathrm{cfu} / \mathrm{g}$. The number of the bacteria after $72 \mathrm{~h}$ of storage was $8.51 \times 10^{5} \mathrm{cfu} / \mathrm{g}$, which means that the cod fillets could be stored for $72 \mathrm{~h}$ in boxes devoid of active coatings. Quite contradictory 
results were obtained by Kuuliala et al. [2] who established that a limit of 7-log cfu/g isolated from cod samples was exceeded after two days of storage in air conditions at $4{ }^{\circ} \mathrm{C}$. The authors contributed intelligent packaging technologies by identifying and quantifying volatile organic compounds (VOC) that indicated spoilage of raw Gadus morhua under MAP and air. They observed that 7-log cfu/g was needed for the onset of exponential VOC increase. When the fish was stored under air condition, Pseudomonas and Shewanella spp. were isolated. These microorganisms have been considered as Specific spoilage organisms (SSOs) of refrigerated or iced marine fish. The authors proved that a high carbon dioxide concentration in MAP packaging inhibited pseudomonads. Sivertsvik et al. [4] noticed that the raw cod fillets may be stored even 14 days, when MA packaging is applied and when the temperature is $0{ }^{\circ} \mathrm{C}$. Typically, MA packaging achieves an increase of acceptable shelf life of about $50 \%$, but it depends on the storage temperature, raw material quality, handling, and gas mixture ratio; and packaging material. The authors demonstrated that the optimum gas mixture ratio was $63 \mathrm{~mL} / 100 \mathrm{~mL} \mathrm{O}_{2}$ and $37 \mathrm{~mL} / 100 \mathrm{~mL} \mathrm{CO}_{2}$. It should be mentioned that shelf life of cod under MA-conditions has been reported from 10 to about 20 days at chilled $\left(0-3{ }^{\circ} \mathrm{C}\right)$ or superchilled $\left(-0.9^{\circ} \mathrm{C}\right)$ temperatures $[2,3,8]$.

The results of this research work demonstrated that the number of bacterial cells stored in boxes covered with Methocel ${ }^{\mathrm{TM}}$ containing polylysine or in boxes containing the PE films coated with MHPC with $\mathrm{ZnO}$ nanoparticles did not go over $10^{7} \mathrm{cfu} / \mathrm{g}$. This suggests that the active coatings improved the quality of cod fillets after storage. It should also be added that coatings with nano $\mathrm{ZnO}$ were more active than coatings with polylysine. Summarizing, it should be mentioned that the boxes containing PE films with $\mathrm{ZnO}$ nanoparticles extended the quality and freshness of the cod fillets after $144 \mathrm{~h}$ storage at $5{ }^{\circ} \mathrm{C}$ under air condition. Similar results were obtained by Singh S. et al. [1] who applied the boxes containing polypropylene films with incorporated $\mathrm{AgSiO}_{2}$ which has both antimicrobial and amine-absorbing properties. The authors studied effect of $\mathrm{PP}+\mathrm{AgSiO}_{2}$ composite $(5.0$ or $10.0 \%)$ on the microbiological, chemical, and colour properties of fresh fish in chilled storage $\left(2 \pm 0.5^{\circ} \mathrm{C}\right)$. The authors indicated that active packaging may lead to the retention of quality, and extension of shelf life of fish, during refrigerated storage for up to seven days. In addition, the packages may also reduce the amount of odour-producing trimethylamine.

\section{Conclusions}

The boxes containing PE films covered with MHPC with $\mathrm{ZnO}$ nanoparticles were found to be the best packaging material to extend the quality and freshness of cod fillets after $144 \mathrm{~h}$ storage at $5^{\circ} \mathrm{C}$.

Acknowledgments: The research work has been funded under the CORNET Programme (as the part of research project Actipoly: CORNET/5/18/2016) by AiF and the German Federal Ministry for Economic Affairs and Energy (BMWi), Germany, by Service Public de Wallonie (SPW), and Agentschap Innoveren \& Ondernemen, Belgium, and by the National Centre for Science and Development (NCBiR), Poland. We would like to acknowledge this support, and we also wish to thank the CORNET Coordination Office and the supporting industrial partners.

Author Contributions: M.M. conceived and designed the experiments, and wrote the paper; M.M. and U.K. performed the microbiological tests; M.M. analyzed the data; M.J. and U.K. performed mechanical and Lab tests; M.M. analyzed the data; P.S. performed dry mass tests; M.M. analyzed the data; M.M. and U.K. prepared reagents/materials; M.M. contributed analysis tools; U.K. performed statistical analysis; and M.M. analyzed the data.

Conflicts of Interest: The authors declare no conflict of interest.

\section{References}

1. Singh, S.; Lee, M.; Gaikwad, K.K.; Lee, Y.S. Antibacterial and amine scavenging properties of silver-silica composite for post-harvest storage of fresh fish. Food Bioprod. Process. 2018, 107, 61-69. [CrossRef]

2. Kuuliala, L.; Hage, Y.A.; Ioannidis, A.-G.; Sader, M.; Kerckhof, F.-M.; Vanderroost, M.; Boon, N.; De Baets, B.; De Meulenaer, B.; Ragaert, P.; et al. Microbiological, chemical and sensory spoilage analysis of raw Atlantic cod (Gadus morhua) stored under modified atmospheres. Food Microbiol. 2018, 70, 232-244. [CrossRef] [PubMed] 
3. Mireles DeWitt, C.A.; Oliveira, A.C.M. Modified Atmosphere Systems and Shelf Life Extension of Fish and Fishery Products. Foods 2016, 5, 48. [CrossRef] [PubMed]

4. Sivertsvik, M. The optimized modified atmosphere for packaging of pre-rigor filleted farmed cod (Gadus morhua) is $63 \mathrm{~mL} / 100 \mathrm{~mL}$ oxygen and $37 \mathrm{~mL} / 100 \mathrm{~mL}$ carbon dioxide. LWT 2007, 40, 430-438. [CrossRef]

5. Ampola, V.G.; Keller, C.L. Shelf Life Extension of Drawn Whole Atlantic Cod, Gadus morhua, and Cod Fillets by Treatment with Potassium Sorbate. Mar. Fish. Rev. 1985, 47, 26-29.

6. Yildirim, S.; Röcker, B.; Pettersen, M.K.; Nilsen-Nygaard, J.; Ayhan, Z.; Rutkaite, R.; Radusin, T.; Suminska, P.; Marcos, B.; Coma, V. Active Packaging Applications for Food. Compr. Rev. Food Sci. Food Saf. 2018, 17, 165-199. [CrossRef]

7. Bartkowiak, A.; Mizielińska, M.; Sumińska, P.; Romanowska-Osuch, A.; Lisiecki, S. Innovations in food packaging materials. In Emerging and Traditional Technologies for Safe, Healthy and Quality Food; Nedovic, V., Raspor, P., Lević, J., Tumbas, V., Barbosa-Canovas, G.V., Eds.; Springer: Berlin, Germany, 2016.

8. Wang, T.; Sveinsdóttir, K.; Magnússon, H. Martinsdóttir, Combined Application of Modified Atmosphere Packaging and Superchilled Storage to Extend the Shelf Life of Fresh Cod (Gadus morhua) Loins. J. Food Sci. 2008, 73, 11-19. [CrossRef] [PubMed]

9. Akbar, A.; Anal, A.K. Zinc oxide nanoparticles loaded active packaging, a challenge study against Salmonella typhimurium and Staphylococcus aureus in readyto-eat poultry meat. Food Control 2014, 38, 88-95. [CrossRef]

10. Marra, A.; Rollo, G.; Cimmino, S.; Silvestre, C. Assessment on the Effects of ZnO and Coated ZnO Particles on iPP and PLA Properties for Application in Food Packaging. Coatings 2017, 7. [CrossRef]

11. Mizielińska, M.; Łopusiewicz, Ł.; Mężyńska, M.; Bartkowiak, A. The influence of accelerated UV-A and Q-SUN irradiation on the antimicrobial properties of coatings containing ZnO nanoparticles. Molecules 2017, 22, 1556. [CrossRef] [PubMed]

12. Azizi, S.; Ahmad, M.B.; Hussein, M.Z.; Ibrahim, N.A. Synthesis, Antibacterial and Thermal Studies of Cellulose Nanocrystal Stabilized ZnO-Ag Heterostructure Nanoparticles. Molecules 2013, 18, 6269-6280. [CrossRef] [PubMed]

13. Mizielińska, M.; Lisiecki, S.; Jotko, M.; Chodzyńska, I.; Bartkowiak, A. The antimicrobial properties of polylactide films covered with ZnO nanoparticles-containing layers. Przem. Chem. 2015, 94, 1000-1003.

14. Noshirvani, N.; Ghanbarzadeh, B.; Mokarram, R.R.; Hashemi, M. Novel active packaging based on carboxymethyl cellulose-chitosan-ZnO NPs nanocomposite for increasing the shelf life of bread. Food Packag. Shelf Life 2017, 11, 106-114. [CrossRef]

15. Oprea, A.E.; Pandel, L.M.; Dumitrescu, A.M.; Andronescu, E.; Grumezescu, V.; Chifiriuc, M.C.; Mogoantă, L.; Bălşeanu, T.-A.; Mogoşanu, G.D.; Socol, G.; et al. Bioactive ZnO Coatings Deposited by MAPLE—An Appropriate Strategy to Produce Efficient Anti-Biofilm Surfaces. Molecules 2016, 21, 220. [CrossRef] [PubMed]

16. Silvestre, C.; Duraccio, D.; Marra, A.; Strongone, V.; Cimmino, S. Development of antimicrobial composite films based on isotactic polypropylene and coated $\mathrm{ZnO}$ particles for active food packaging. Coatings 2016, 6 . [CrossRef]

17. Castro-Mayorgaa, J.L.; Fabraa, M.J.; Pourrahimib, A.M.; Olssonb, R.T.; Lagarona, J.M. The impact of zinc oxide particle morphology as anantimicrobial and when incorporated inpoly(3-hydroxybutyrate-co-3-hydroxyvalerate)films for food packaging and food contact surfacesapplications. Food Bioprod. Process. 2017, 101, 32-44. [CrossRef]

18. Rahman, P.M.; Mujeeb, V.M.A.; Muraleedharan, K. Flexible chitosan-nano ZnO antimicrobial pouches as a new material for extending the shelf life of raw meat. Int. J. Biol. Macromol. 2017, 97, 382-391. [CrossRef] [PubMed]

19. Emamifar, A.; Kadivar, M.; Shahedi, M.; Soleimanianzad, S. Evaluation of nanocomposite packaging containing Ag and $\mathrm{ZnO}$ on shelf life of fresh orange juice. Innov. Food Sci. Emerg. Technol. 2010, 11, 742-748. [CrossRef]

20. Li, X.; Li, W.; Jiang, Y.; Ding, Y.; Yun, J.; Yao, T.; Zhang, P. Effect of nano-ZnO-coated active packaging on quality of fresh-cut 'Fuji' apple. Int. J. Food Sci. Technol. 2011, 46, 1947-1955. [CrossRef]

21. Li, W.; Zhang, C.; Chi, H.; Li, L.; Lan, T.; Han, P.; Chen, H.; Qin, Y. Development of Antimicrobial Packaging Film Made from Poly(Lactic Acid) Incorporating Titanium Dioxide and Silver Nanoparticles. Molecules 2017, 22, 1170. [CrossRef] [PubMed] 
22. Li, W.; Li, L.; Zhang, H.; Yuan, M.; Qin, Y. Evaluation of PLA nanocomposite films on physicochemical and microbiological properties of refrigerated cottage cheese. J. Food Process. Preserv. 2017. [CrossRef]

23. Zinoviadou, K.G.; Koutsoumanis, K.P.; Biliaderis, C.G. Physical and thermo-mechanical properties of whey protein isolate films containing antimicrobials, and their effect against spoilage flora of fresh beef. Food Hydrocoll. 2010, 24, 49-59. [CrossRef]

24. Ünalan, I.U.; Uçar, K.D.A.U.; Arcan, I.; Korel, F.; Yemenicioğlu, A. Antimicrobial Potential of Polylysine in Edible Films. Food Sci. Technol. Res. 2011, 17, 375-380. [CrossRef]

25. PN-ISO 11036:1999 Standard. Available online: http://sklep.pkn.pl/pn-iso-11036-1999p.html (accessed on 10 March 2018).

26. PN-EN ISO 4833-2:2013-12. Available online: http:/ / sklep.pkn.pl/pn-en-iso-4833-2-2013-12p.html (accessed on 10 March 2018).

27. PN-ISO 17410:2004. Available online: http://sklep.pkn.pl/pn-iso-17410-2004p.html (accessed on 10 March 2018).

28. PN-EN ISO 6887-3:2017-05. Available online: http://sklep.pkn.pl/pn-en-iso-6887-3-2017-05e.html (accessed on 10 March 2018).

29. Tokarczyk, G.; Bienkiewicz, G.; Suryn, J. Comparative analysis of the quality parameters and the fatty acid composition of two economically important batlic fish: cod, Gadus Morhua and Flounder, Platichthys flesus (Actinopterygii) subjected to iced storage. Acta Ichtiol. Piscat. 2017, 47, 249-258. [CrossRef]

30. Cheng, J.H.; Sun, D.W.; Han, Z.; Zeng, X.A. Texture and Structure Measurements and Analyses for Evaluation of Fish and Fillet Freshness Quality: A Review. Compr. Rev. Food Sci. Food Saf. 2014, 13, 52-61. [CrossRef]

31. Cardoso, C.M.L.; Mendes, R.; Nunes, M.L. Instrumental Texture and Sensory Characteristics of Cod Frankfurter Sausages. Int. J. Food Prop. 2009, 12, 625-643. [CrossRef]

32. Garavand, F.; Rouhi, M.; Razavi, S.H.; Cacciotti, I. Improving the integrity of natural biopolymer films used in food packaging by crosslinking approach: A review. Int. J. Biol. Macromol. 2017, 104, 687-707. [CrossRef] [PubMed]

33. Michalczyk, M.; Surówka, K. Microstructure and instrumentally measured textural changes of rainbow trout (Oncorhynchus mykiss) gravads during production and storage. J. Sci. Food Agric. 2009, 89, 1942-1949. [CrossRef]

34. Bahuaud, D.; Gaarder, M.; Veiseth-Kent, E.; Thomassen, M. Fillet texture and protease activities in different families of farmed Atlantic salmon (Salmo salar L.). Aquaculture 2010, 310, 213-220. [CrossRef]

35. Ayala, M.D.; Santaella, M.; Martínez, C.; Periago, M.J.; Alfonso Blanco, A.; Vázquez, J.M.; Albors, O.L. Muscle tissue structure and flesh texture in gilthead sea bream, Sparus aurata L., fillets preserved by refrigeration and by vacuum packaging. LWT Food Sci. Technol. 2011, 44, 1098-1106. [CrossRef] 